\title{
Functional N-Methyl-D-Aspartate Receptors Are Expressed in Cone-Driven Horizontal Cells in Carp Retina
}

\author{
Yin Shen Min Zhang Ying Jin Xiong-Li Yang \\ Institute of Neurobiology, Institutes of Brain Science, Fudan University, Shanghai, China
}

\section{Key Words}

NMDA $\cdot$ NMDA receptor $\cdot$ Retina $\cdot$ Horizontal cell $\cdot$ Patch clamp $\cdot \mathrm{Ca}^{2+}$

\begin{abstract}
Glutamate works as a major excitatory neurotransmitter in the vertebrate retina. Whole-cell recordings made from isolated carp cone horizontal cells ( $\mathrm{H} 1$ cells) showed that $\mathrm{N}$ methyl-D-aspartate (NMDA), co-applied with glycine, induced inward currents that were blocked by the NMDA receptor competitive antagonist D-2-amino-5-phosphonopentanoate (D-AP5) and 5,7-dichlorokynurenic acid (DCKA), a selective NMDA receptor antagonist acting at the glycine site on the NMDA receptor complex. Moreover, calcium imaging showed that NMDA caused a significant elevation of intracellular calcium levels $\left(\left[\mathrm{Ca}^{2+}\right]_{\mathrm{i}}\right)$ of $\mathrm{H} 1$ cells, which was also blocked by D-AP5. In contrast, neither inward currents nor changes in $\left[\mathrm{Ca}^{2+}\right]_{i}$ could be induced by NMDA in rod horizontal cells ( $\mathrm{H} 4$ cells). Intracellular recordings made from $\mathrm{H} 1$ cells in the isolated retina, superfused with Ringer's containing $1 \mathrm{mM} \mathrm{Mg}{ }^{2+}$, in the dark demonstrated that NMDA reduced the light-off overshoot of $\mathrm{H} 1$ cells. We therefore conclude that the functional NMDA receptor is expressed in carp $\mathrm{H} 1$ cells, from which this receptor has been thought to be absent, and this receptor may play a role in modulating cone-driven signal of horizontal cells in the dark.
\end{abstract}

Copyright $\odot 2006$ S. Karger AG, Basel

\section{Introduction}

Ionotropic glutamate receptors have been described as either N-methyl-D-aspartate (NMDA), or non-NMDA subtypes, depending on whether they are activated by NMDA. NMDA receptors are heteromeric in that they are composed of the NR1 subunit (which binds glycine) and the NR2 subunit (which binds glutamate) [1]. NMDA receptors are up to 70 times more permeable to $\mathrm{Ca}^{2+}$ than non-NMDA receptors, and once activated, produce long lasting effects on the postsynaptic neurons through changing the $\mathrm{Ca}^{2+}$ permeability $[2,3]$. NMDA receptors are known to be involved in a variety of physiological and pathological processes in the CNS. While these receptors have been shown to play functional roles in the inner retina [4-6], the data concerning functions of NMDA receptors in the outer retina are rather fragmentary. As far as horizontal cells (HCs) that are responsible for lateral interaction in the distal retina are concerned, it is generally thought that NMDA receptors are absent from these cells $[6,7]$ and it is the AMPA receptor that mediates signal transfer from photoreceptors to these cells in both mammalian and non-mammalian retinas [8-10]. The only exception from this general scheme is the catfish HC, which expresses NMDA receptors [11, 12]. It should be noted, however, that there is anatomical evidence, suggesting the existence of these receptors in HCs of rat and human [13-15].

\section{KARGER}

Fax +41613061234 E-Mail karger@karger.ch www.karger.com
Dr. Xiong-Li Yang

Institute of Neurobiology, Fudan University

138 Yixueyuan Road

Shanghai, 200032 (China)

Tel. +86 216422 1975, Fax +86 215423 7647, E-Mail xlyang@fudan.edu.cn 
In the present work we show by patch clamp techniques and calcium imaging that NMDA application induced a whole-cell current and an increase in intracellular calcium levels $\left[\mathrm{Ca}^{2+}\right]_{\mathrm{i}}$ in carp cone-driven $\mathrm{HCs}$ (H1 cells), but not in rod-driven ones (H4 cells), which was suppressed by D-2-amino-5-phosphonopentanoate (D-AP5), suggesting the presence of functional NMDA receptors in the $\mathrm{H} 1$ cells. Possible functional roles of these receptors were analyzed by intracellular recording in the isolated superfused retina.

\section{Materials and Methods}

\section{Animals}

Experiments were performed on the adult Crucian carp (Carassius auratus) retina, as described previously [16]. The animal, maintained under a 12:12 h light:dark cycle for at least 1 week, was dark-adapted for $20 \mathrm{~min}$ prior to an experiment and then decapitated. The eyeball was enucleated and hemisected. Adequate care was taken to minimize pain and discomfort to animals in accordance with the National Institutes of Health guidelines for animal experimentation.

\section{Whole-Cell Patch Clamp Recording}

Dissociation of retinal neurons and whole-cell recording were conducted following the procedures described in detail previously [8]. In brief, freshly dissociated HCs were commonly bathed in $\mathrm{Mg}^{2+}$-free Ringer's containing (in $\mathrm{mM}$ ) NaCl 145, $\mathrm{KCl}$ $5, \mathrm{CaCl}_{2}$ 2, HEPES 10 and glucose 16, $\mathrm{pH}$ adjusted to 7.4 with $\mathrm{NaOH}$. H1 and $\mathrm{H} 4$ cells were identified by their characteristic morphology [17]. Whole-cell membrane currents of HCs, voltage-clamped at $-60 \mathrm{mV}$, were recorded with pipettes of 5-7 $\mathrm{M} \Omega$ resistance, connected to an EPC9/2 patch clamp amplifier (Heka, Germany). The liquid junction potential was compensated online. That is, the liquid potential for the solution used was calculated and then added to the nominal holding potential for the amplifier. Fast capacitance and cell capacitance transients were cancelled by the circuit of the amplifier. $70 \%$ of the series resistance of the recording electrode was compensated. Analog signals were filtered at $2 \mathrm{kHz}$, sampled at $10 \mathrm{kHz}$, and stored on PC hard disk for further off-line analysis. The data were all presented as mean \pm SEM. Paired Student's $t$ test was performed for statistical analysis.

All solutions were delivered using a stepper motor-based rapid solution changer RSC-100 (Bio-Logic Science Instruments, France), with which solution exchange could be completed in a few milliseconds [8]. The recorded cells were lifted from the dish bottom and completely bathed in the solution. In all experiments, NMDA was always co-applied with $40 \mu \mathrm{M}$ glycine, which alone could not induce detectable current, unless otherwise specified.

\section{Calcium Imaging}

$\left[\mathrm{Ca}^{2+}\right]_{\mathrm{i}}$ in HCs were monitored with fura-2 AM (Dojindo, Kumamoto, Japan), a membrane permeable indicator, following a procedure described previously [18]. Fura-2 AM (1 mM) was dis- solved in 20\% Pluronic F-127 (w/v, DMSO) and then added to Ringer's at a dilution of 1:500. Fura-2 AM-containing Ringer's was added to a chamber to give a final concentration of $2 \mu \mathrm{M}$ fura$2 \mathrm{AM}$. Isolated HCs were incubated in the dye solution for $30 \mathrm{~min}$ at room temperature and then perfused with dye-free Ringer's for $5 \mathrm{~min}$ before an experiment. Fluorescence images were acquired with an inverted microscope (IX-70; Olympus Optical, Tokyo, Japan) equipped with a digital CCD camera (C4742-95-12NRB; Hamamatsu Photonics, Hamamatsu, Japan). A high-speed scanning polychromatic light source (C7773; Hamamatsu Photonics) was used for alternate excitations at wavelengths of 340 and $380 \mathrm{~nm}$. The fluorescence intensities at both wavelengths (F340 and F380) were measured every $0.5 \mathrm{~s}$, and images were obtained using PC-based software (Aquacosmos version 1.2; Hamamatsu Photonics, Hamamatsu, Japan). The ratio between the two was proportional to $\left[\mathrm{Ca}^{2+}\right]_{i}$ of the cell under study. Before an experiment, a bath ground level of fluorescence (attributable to autofluorescence and camera noise) was determined and subtracted from all the data obtained. Solutions were delivered using a DADVC voltage commend valve control system PR-10 (Scientific Instrument, New York, N.Y., USA).

\section{Intracellular Recording and Photostimulation}

Intracellular recordings were conventionally made from $\mathrm{HCs}$ in the isolated, superfused retina [16], superfused with oxygenated $\left(95 \% \mathrm{O}_{2}, 5 \% \mathrm{CO}_{2}\right)$ Ringer's containing $1 \mathrm{mM} \mathrm{Mg}^{2+}$ buffered to $\mathrm{pH}$ 7.7. The retina was illuminated diffusely from the photoreceptor side by a dual-beam photostimulator, which provided two coincident $8 \mathrm{~mm}$-diameter spots around the electrode tip. Light intensities and wavelengths of the two beams were changed by calibrated neutral density and interference filters. All light intensities referred to in the text are in log units relative to the maximum intensity $(\log \mathrm{I}=0)$, which was $5.5 \times 10^{13}$ quanta $\mathrm{cm}^{-2} \mathrm{~s}^{-1}$. Glass microelectrodes filled with $4 \mathrm{M}$ potassium acetate and having a tip resistance of 70-150 M $\Omega$, in combination with an amplifier (MEZ 8300; Nihon Koden Corporation, Tokyo, Japan), were employed to record intracellular potentials. Light responses of $\mathrm{H} 1$ cells were identified by reference to previously well-established criteria [19].

\section{Chemicals}

All chemicals were obtained from Sigma Chemical Company (St. Louis, Mo., USA), unless otherwise specified.

\section{Results}

\section{NMDA Induces Inward Currents from Isolated H1 Cells}

In 96 out of $98 \mathrm{H} 1$ cells tested, NMDA induced inward currents. Figure 1a shows desensitizing current responses induced by NMDA of increasing concentrations from an isolated $\mathrm{H} 1$ cell, voltage-clamped at $-60 \mathrm{mV}$. The threshold concentration of NMDA was around $10 \mu \mathrm{M}$. With the increase of NMDA concentration, the peak current steadily increased in size and reached a maximum value at $1 \mathrm{~mm}$. The desensitization course of the current 


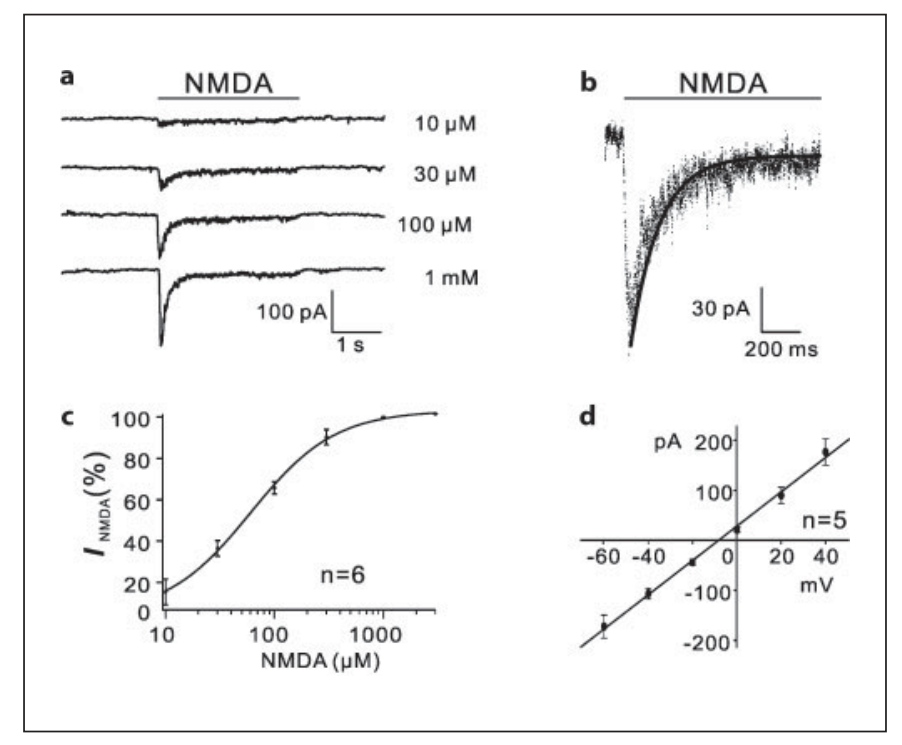

Fig. 1. NMDA-induced currents of carp H1 cells. a Current responses of an isolated $\mathrm{H} 1$ cell, voltage-clamped at $-60 \mathrm{mV}$, to NMDA of increasing concentrations. These currents exhibited significant desensitization. b Desensitization course of the current response to $1 \mathrm{mM} \mathrm{NMDA}$ is fitted by a monoexponential function (curve), yielding a time constant of $157 \mathrm{~ms}$. c Average dose-response relationship of NMDA currents obtained in six H1 cells. The data for each cell were normalized by the maximum response of that cell to $3 \mathrm{mM}$ NMDA, and the normalized data were then averaged. The curve is drawn according to the equation: $\mathrm{I} / \mathrm{I}_{\max }=1 /\left[1+\left(\mathrm{EC}_{50} / \mathrm{NMDA}\right)^{\mathrm{n}}\right]$, yielding an $\mathrm{EC}_{50}$ of $52.3 \pm$ $4.3 \mu \mathrm{M}$. Error bars represent SEM. d Averaged I-V curve obtained in five $\mathrm{H} 1$ cells, yielding a reversal potential of $-8.1 \mathrm{mV}$.

induced by $1 \mathrm{mM}$ NMDA was well fitted by equation $\mathrm{I}(\mathrm{t})=\mathrm{A} X \exp (-\mathrm{t} / \tau)+\mathrm{C}$, yielding a time constant $(\tau)$ of $157 \mathrm{~ms}$ (fig. 1b). The average value of $\tau$ was $163.3 \pm$ $13.4 \mathrm{~ms}(\mathrm{n}=7)$.

Dose-response relationships for peak currents were determined in six $\mathrm{H} 1$ cells (fig. 1C). The averaged data were well fitted by the curve described by $\mathrm{I} / \mathrm{I}_{\max }=$ $1 /\left[1+\left(\mathrm{EC}_{50} / \mathrm{NMDA}\right)^{\mathrm{n}}\right]$, with a $\mathrm{EC}_{50}$ of $52.3 \pm 4.3 \mu \mathrm{M}$, which is similar to that of catfish HCs $(37 \mu \mathrm{M})$ [12].

Current responses of $\mathrm{H} 1$ cells to $100 \mu \mathrm{M}$ NMDA were recorded at different holding potentials $(40,20,0,-20$, -40 and $-60 \mathrm{mV}$ ), and currents commonly reversed polarity between $0 \mathrm{mV}$ and $-20 \mathrm{mV}$. The averaged I-V curve based on the data obtained in five $\mathrm{H} 1$ cells was linear in the whole voltage range from -60 to $40 \mathrm{mV}$, and the reversal potential derived from the curve was $-8.1 \mathrm{mV}$ (fig. 1d).

NMDA-induced currents from $\mathrm{H} 1$ cells $(\mathrm{n}=36)$ were reversibly blocked by D-AP5 of $100 \mu \mathrm{M}$, an NMDA recep-

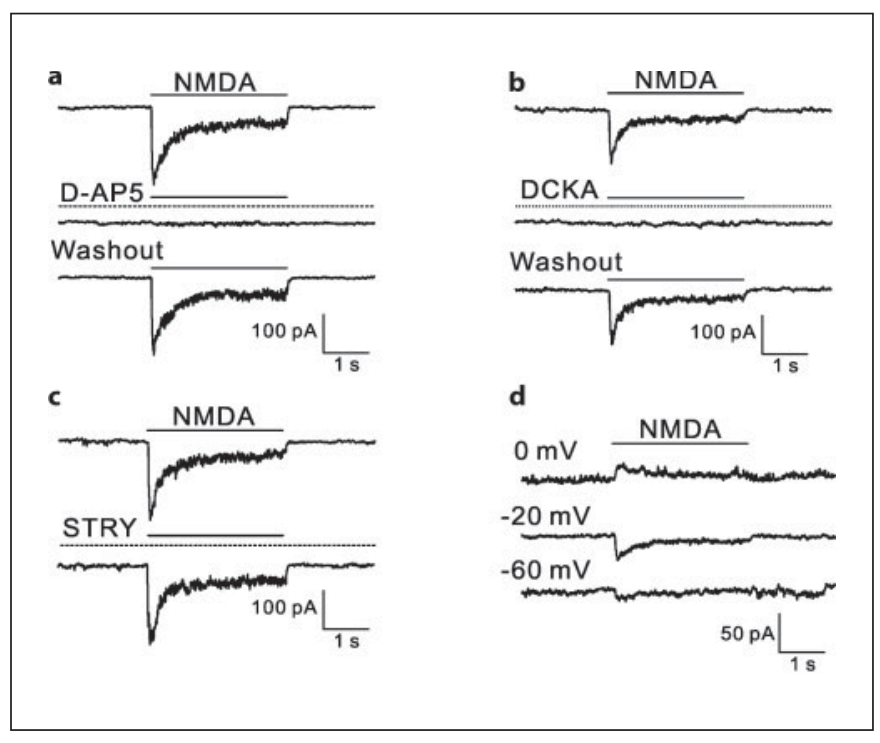

Fig. 2. NMDA-induced currents from $\mathrm{H} 1$ cells are blocked by $\mathrm{D}-$ AP5 and DCKA, but not strychnine. $\mathbf{a}, \mathbf{b}$ Currents induced in two $\mathrm{H} 1$ cells by $100 \mu \mathrm{M}$ NMDA were reversibly blocked by $100 \mu \mathrm{M} \mathrm{D}-$ AP5 (a) and by $20 \mu \mathrm{M}$ DCKA (b), respectively. c Strychnine (STRY) of $20 \mu \mathrm{M}$ could not block the NMDA-induced current. All NMDA-induced currents shown in a-c were recorded in $\mathrm{Mg}^{2+}$ free Ringer's. d NMDA-induced currents from $\mathrm{H} 1$ cell, showing voltage-dependence in the presence of $\mathrm{Mg}^{2+}$. In Ringer's containing $1 \mathrm{mM} \mathrm{Mg}^{2+}$, NMDA of $100 \mu \mathrm{M}$ only induced a small inward current when clamped at $-60 \mathrm{mV}$ and the current was maximal at around $-20 \mathrm{mV}$. Note that an outward current was induced at $0 \mathrm{mV}$.

tor competitive antagonist (fig. 2a). The NMDA currents could be also blocked by the NMDA receptor glycine site blocker 5,7-dichlorokynurenic acid (DCKA) of $20 \mu \mathrm{M}$ $(n=9)$, as illustrated in figure $2 \mathrm{~b}$. On the other hand, the glycine receptor antagonist strychnine $(20 \mu \mathrm{M})$ failed to affect the NMDA currents (fig. $2 \mathrm{c}, \mathrm{n}=8$ ). Furthermore, the NMDA currents exhibited marked voltage-dependence in the presence of extracellular $\mathrm{Mg}^{2+}$, as shown in mammalian central neurons [2]. Figure $2 \mathrm{~d}$ shows that $100 \mu \mathrm{M}$ NMDA induced a small inward current of less than $10 \mathrm{pA}$ in Ringer's containing $1 \mathrm{mM} \mathrm{Mg}^{2+}$ when clamped at $-60 \mathrm{mV}$, and the inward current was maximal around $-20 \mathrm{mV}$. An outward current was induced when the holding potential was shifted to a voltage more positive than $0 \mathrm{mV}$.

In contrast, no currents could be induced from $\mathrm{H} 4$ cells $(\mathrm{n}=7)$ by NMDA application, even at a concentration as high as $1 \mathrm{~mm}$ (data not shown). 


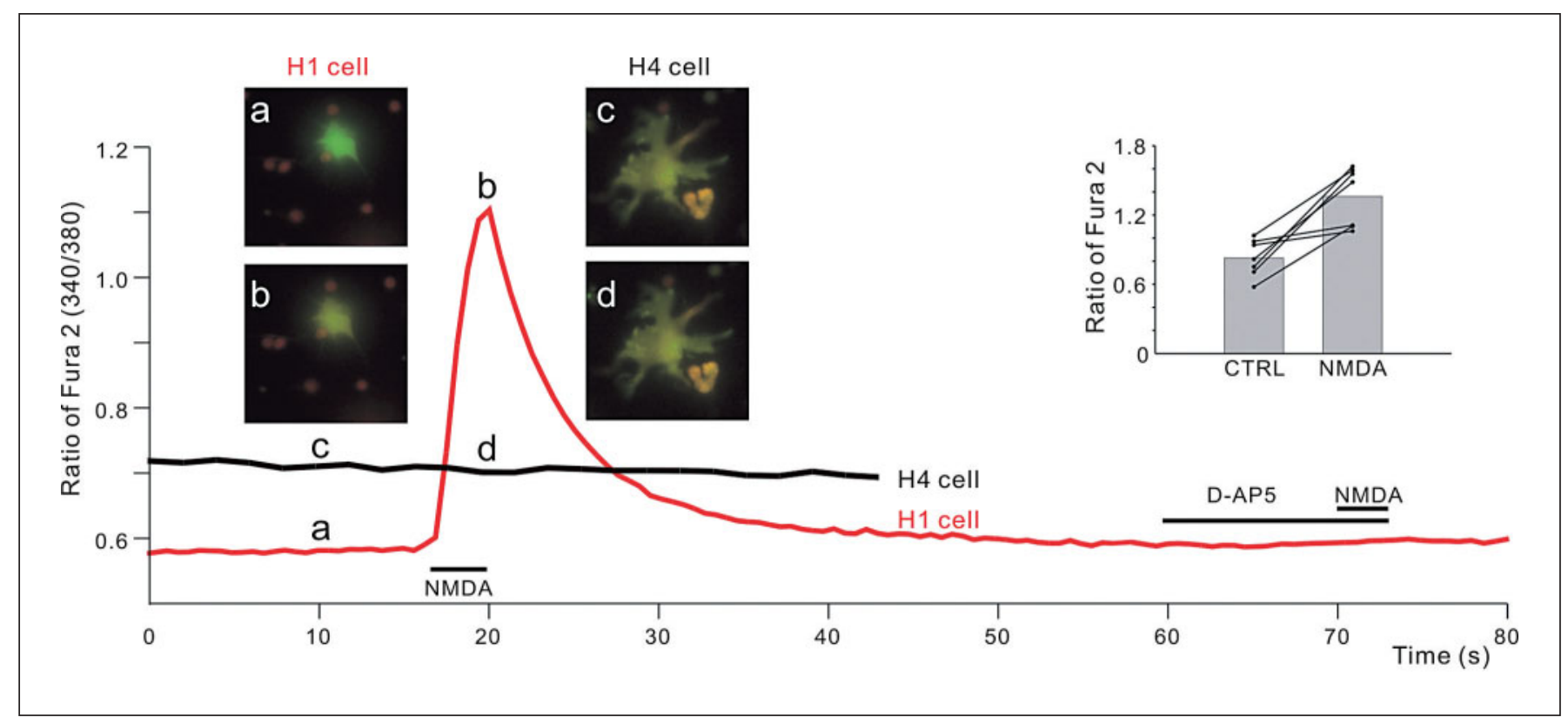

Fig. 3. NMDA causes a significant increase in $\left[\mathrm{Ca}^{2+}\right]_{\mathrm{i}}$ in $\mathrm{H} 1$ cells. Continuous recording of $\left[\mathrm{Ca}^{2+}\right]_{\mathrm{i}}$ from an isolated $\mathrm{H} 1$ cell (red line), represented by the ratio of fura-2 AM fluorescence at 340 and $380 \mathrm{~nm}$, using a fluorescence microscope equipped with a CCD camera. NMDA of $100 \mu \mathrm{M}$ was puffed to this cell for $3 \mathrm{~s}$, which remarkably increased $\left[\mathrm{Ca}^{2+}\right]_{i}$ from 0.577 to 1.104 , and the change was blocked in the presence of $100 \mu \mathrm{M}$ D-AP5. a, b CCD pictures of the cell taken before NMDA application and when
$\left[\mathrm{Ca}^{2+}\right]_{\mathrm{i}}$ reached a maximum, respectively. Average changes in $\left[\mathrm{Ca}^{2+}\right]_{\mathrm{i}}$ caused by $100 \mu \mathrm{M}$ NMDA obtained in seven $\mathrm{H} 1$ cells are summarized in the bar chart shown in the inset. Data obtained in individual cells are represented by solid lines. No change in $\left[\mathrm{Ca}^{2+}\right]_{\mathrm{i}}$ was produced by $100 \mu \mathrm{M}$ NMDA in the H4 cell (black line). c, d CCD pictures of the $\mathrm{H} 4$ cell taken before and after NMDA application, respectively.
Increase of Intracellular Calcium Levels in H1 Cells by Activation of NMDA Receptors

There is abundant evidence that activation of NMDA receptors modulated $\left[\mathrm{Ca}^{2+}\right]_{i}$ by changing the permeability to $\mathrm{Ca}^{2+}[3,11,20]$. This was also the case in the $\mathrm{H} 1$ cells. Figure 4 shows the result obtained in an $\mathrm{H} 1$ cell, by monitoring NMDA-induced changes in $\left[\mathrm{Ca}^{2+}\right]_{i}$. After puffing $100 \mu \mathrm{M}$ NMDA to the cell for $3 \mathrm{~s}$ in the presence of $40 \mu \mathrm{M}$ glycine, $\left[\mathrm{Ca}^{2+}\right]_{\mathrm{i}}$, represented as the ratio (F340/ F380), increased from 0.577 (a) to 1.103 (b) in $3 \mathrm{~s}$ (red line). Figures $3 \mathrm{a}$ and $3 \mathrm{~b}$ present the two CCD images of the cell taken before NMDA application and when NMDA of $100 \mu \mathrm{M}$ was applied for $3 \mathrm{~s}$, respectively. $\left[\mathrm{Ca}^{2+}\right]_{\mathrm{i}}$ was significantly increased in both soma and dendrites $(\mathrm{n}=$ 7). The change in $\left[\mathrm{Ca}^{2+}\right]_{\mathrm{i}}$ was completely blocked by coapplication of $100 \mu \mathrm{M}$ D-AP5 $(\mathrm{n}=4)$. Statistical analysis of the data pooled from seven $\mathrm{H} 1$ cells is summarized in the inset. The increase in $\left[\mathrm{Ca}^{2+}\right]_{\mathrm{i}}$ following application of NMDA was observed in all the cells, with an average of $70.2 \pm 16.7 \%(\mathrm{p}<0.01)$. In contrast, $100 \mu \mathrm{M}$ NMDA did not cause any discernable change in $\left[\mathrm{Ca}^{2+}\right]_{\mathrm{i}}$ in $\mathrm{H} 4$ cells $(\mathrm{n}=5)$. The result obtained in an $\mathrm{H} 4$ cell is shown by the black line in figure 3 , and the two CCD images of the cell taken before and after the application of $100 \mu \mathrm{M}$ NMDA are shown in figure $3 \mathrm{c}$ and figure $3 \mathrm{~d}$, respectively.

\section{Effects of NMDA on the Membrane Potential and}

Light Responses of $\mathrm{H} 1 \mathrm{Cells}$

Figure 4a shows the effects of NMDA on the membrane potential and light responses of an $\mathrm{H} 1$ cell recorded in the isolated retina, superfused with Ringer's containing $1 \mathrm{mM} \mathrm{Mg}^{2+}$. Test flashes of $500 \mathrm{~nm}(\log \mathrm{I}=-0.6)$ and $680 \mathrm{~nm}(\log \mathrm{I}=-0.6)$ were alternately presented in the dark, which activate short wavelength-sensitive cones, most likely green-sensitive cones, and red-sensitive cones [21]. NMDA of $100 \mu \mathrm{M}$ depolarized the membrane potential from -25 to $-15 \mathrm{mV}$, which was associated with a decrease of the hyperpolarizing light responses (see also fig. $4 \mathrm{~b}$ ). The relative reduction of the hyperpolarizing response were $23.01 \pm 9.96 \%$ and $25.93 \pm 10.89 \%(n=6)$ for red and green test lights, respectively. It is of interest that the off-overshoot of the green light-induced response 


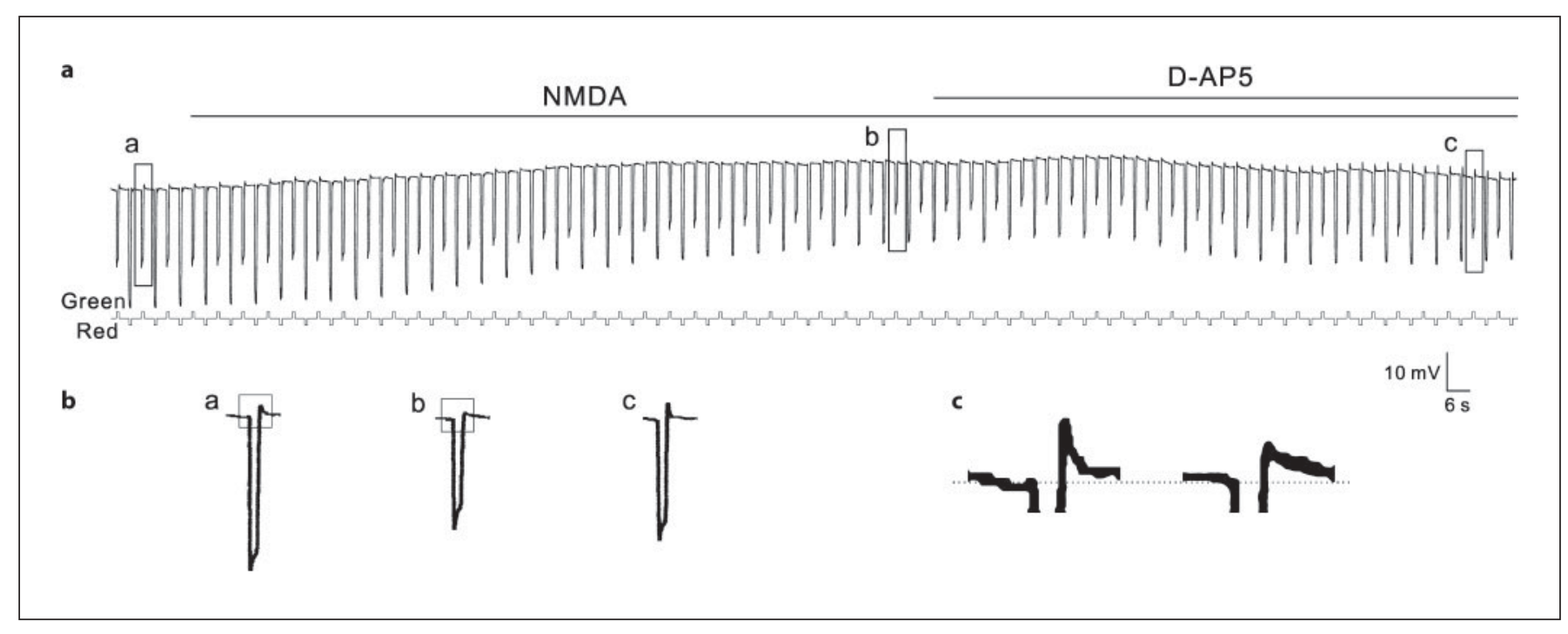

Fig. 4. NMDA reduces the light-off overshoot of $\mathrm{H} 1$ cell. Intracellular recordings were made from the isolated carp retina, superfused with Ringer's containing $1 \mathrm{mM} \mathrm{Mg}^{2+}$. a Light responses were induced by test light flashes of $500 \mathrm{~nm}(\log \mathrm{I}=-0.6)$ and $680 \mathrm{~nm}$ $(\log I=-0.6)$ in the dark, which were alternately presented at intervals of $3 \mathrm{~s}$. NMDA of $100 \mu \mathrm{M}$ depolarized the cell from -25 to $-15 \mathrm{mV}$ and reduced the amplitude of the hyperpolarizing re- sponses. b Responses excerpted from the continuous trace at different times ( $a, b$ and $c$ ) at a faster time scale and a larger voltage scale. $\mathbf{c}$ Parts of light responses a and b shown in $\mathbf{b}$ are shown in much larger voltage and faster time scales. Note that the off-overshoot of the response elicited by the green flash was reduced and the steady-state membrane potential following the off-overshoot tended to be enhanced. was reduced in size and the steady-state membrane potential following the overshoot tended to be increased, as clearly seen in figure $4 \mathrm{c}$. The average reduction of the offovershoot caused by $100 \mu \mathrm{M}$ NMDA in seven $\mathrm{H} 1$ cells was $47.82 \pm 22.14 \%$.

\section{Discussion}

\section{Expression of Functional NMDA Receptors in $\mathrm{H} 1$}

Cells, but Not H4 Cells

While functional NMDA receptors are extensively expressed in the inner retina, which are involved in signaling from bipolar cells to amacrine and ganglion cells [5, 22,23 ], it is generally thought that HCs express the AMPA receptor subtype, and the NMDA receptor is absent from HCs. In the present work, however, we showed that NMDA induced inward currents from $\mathrm{H} 1$ cells, but not from $\mathrm{H} 4$ cells, in a dose-dependent manner. These currents showed desensitization, with a time constant of $\sim 160 \mathrm{~ms}$, similar to that obtained in other central neurons [24], but much longer than that for the AMPA receptor-mediated current of this cell type $(\sim 1.5 \mathrm{~ms})$ [8]. The NMDA-induced currents were completely blocked by
D-AP5 and DCKA, but not by strychnine, and they showed voltage-dependence in the presence of $\mathrm{Mg}^{2+}$. Moreover, NMDA induced a significant increase in $\left[\mathrm{Ca}^{2+}\right]_{\mathrm{i}}$ in $\mathrm{H} 1$ cells, but not in $\mathrm{H} 4$ cells, and the increase was blocked by D-AP5. All these results suggest that the carp $\mathrm{H} 1$ cell expresses the functional NMDA receptor, in addition to the AMPA receptor [8], and this receptor type is involved in modulation of signal transfer between cones, but not rods, and HCs. Expression of NMDA receptors in HCs might have been overlooked previously in this species and other lower vertebrates. It is noteworthy that 6-cyano-7-nitroquinoxaline-2,3-dione (CNQX), a selective antagonist of non-NMDA receptors, blocks the actions of kaniate and AMPA in salamander HCs, but not that of glutamate, indicative of the existence of receptors other than AMPA receptors $[25,26]$. It will be of interest to determine whether functional NMDA receptors may also be expressed in HCs of other species.

\section{Possible Physiological Roles of NMDA Receptors of Carp H1 Cells}

Due to the voltage-dependent block of NMDA receptors by $\mathrm{Mg}^{2+}$, these receptors are not quite activated in external medium containing physiological concentra- 
tions of $\mathrm{Mg}^{2+}(\sim 1 \mathrm{mM})$ at resting membrane potentials of most central neurons [2]. The situation in HCs, however, is quite different in that these cells are depolarized to around $-20 \mathrm{mV}$ in the dark due to the activation of the AMPA receptor by glutamate tonically released from photoreceptors. In carp H1 cells the NMDA receptor-mediated inward current was maximal at around $-20 \mathrm{mV}$, which is in agreement with that reported in other central neurons [2]. These suggest that this receptor may play a physiological role in signal transfer from cones to HCs in the dark. As shown in figure 4c, NMDA reduced the size of the off-overshoot and tended to increase the depolarized steady-state membrane potential. This effect of NMDA is reminiscent of a recent study of Davis and Linn [11]. They reported that activation of NMDA receptors in isolated catfish HCs produced a down regulation of voltage-gated $\mathrm{Na}^{+}$and $\mathrm{Ca}^{2+}$ currents, which plays a role in shaping the off-overshoot under current clamp [27], and thus reduced the simulated depolarized off-overshoot and steady-state membrane potential elicited by injection of depolarizing currents. These changes of the off response of the $\mathrm{H} 1$ cell suggest that NMDA receptors in the outer retina may be involved in modulating visual information concerning dark/light transition.

\section{Acknowledgements}

This work was supported by grants from the National Program of Basic Research sponsored by the Ministry of Science and Technique of China (2006CB5008), National Science Foundation of China (90408003, 30570593), the Shanghai Commission of Science and Technology (C010607) and the '211' Project of the Ministry of Education of China. We thank Dr. Hua Zhang for her kind assistance in calcium imaging.

\section{References}

-1 McBain CJ, Mayer ML: N-methyl-D-aspartic acid receptor structure and function. Physiol Rev 1994;74:723-760.

-2 Ozawa S, Kamiya H, Tsuzuki K: Glutamate receptors in the mammalian central nervous system. Prog Neurobiol 1998;54:581-618.

3 MacDermott AB, Mayer ML, Westbrook GL, Smith SJ, Barker JL: NMDA-receptor activation increases cytoplasmic calcium concentration in cultured spinal cord neurones. $\mathrm{Na}$ ture 1986;321:519-522.

4 Chen S, Diamond JS: Synaptically released glutamate activates extrasynaptic NMDA receptors on cells in the ganglion cell layer of rat retina. J Neurosci 2002;22:2165-2173.

5 Zhou C, Dacheux RF: All amacrine cells in the rabbit retina possess AMPA-, NMDA-, GABA-, and glycine-activated currents. Vis Neurosci 2004;21:181-188.

6 Yang XL: Characterization of receptors for glutamate and GABA in retinal neurons. Prog Neurobiol 2004;73:127-150.

7 Thoreson WB, Witkovsky P: Glutamate receptors and circuits in the vertebrate retina. Prog Retin Eye Res 1999;18:765-810.

$\checkmark 8$ Lu T, Shen Y, Yang XL: Desensitization of AMPA receptors on horizontal cells isolated from Crucian carp retina. Neurosci Res 1998;31:123-135.

-9 Blanco R, de la Villa P: Ionotropic glutamate receptors in isolated horizontal cells of the rabbit retina. Eur J Neurosci 1999;11:867873.

10 Eliasof S, Jahr CE: Rapid AMPA receptor desensitization in catfish cone horizontal cells. Vis Neurosci 1997;14:13-18.
11 Davis SF, Linn CL: Activation of NMDA receptors linked to modulation of voltage-gated ion channels and functional implications. Am J Physiol Cell Physiol 2003;284:C757-C768.

12 O’Dell TJ, Christensen BN: Horizontal cells isolated from catfish retina contain two types of excitatory amino acid receptors. J Neurophysiol 1989;61:1097-1109.

13 Gründer T, Kohler K, Kaletta A, Guenther E: The distribution and developmental regulation of NMDA receptor subunit proteins in the outer and inner retina of the rat. J Neurobiol 2000;44:333-342.

14 Picaud S, Hicks D, Forster V, Sahel J, Dreyfus $\mathrm{H}$ : Adult human retinal neurons in culture: physiology of horizontal cells. Invest Ophthalmol Vis Sci 1998;39:2637-2648.

15 Fletcher EL, Hack I, Brandstätter JH, Wässle $\mathrm{H}$ : Synaptic localization of NMDA receptor subunits in the rat retina. J Comp Neurol 2000;420:98-112.

16 Shen Y, Chen L, Ping Y, Yang XL: Glycine modulates the center response of ON-type rod-dominant bipolar cells in carp retina. Brain Res Bull 2005;67:492-497.

17 Dowling JE, Pak MW, Lasater EM: White perch horizontal cells in culture: methods, morphology and process growth. Brain Res 1985;360:331-338

18 Yu YC, Cao LH, Yang XL: Modulation by brain natriuretic peptide of GABA receptors on rat retinal ON-type bipolar cells. J Neurosci 2006;26:696-707.

19 Xu HP, Luo DG, Yang XL: Signals from cone photoreceptors to L-type horizontal cells are differentially modulated by low calcium in carp retina. Eur J Neurosci 2001;13:14111419 .
20 Micu I, Jiang Q, Coderre E, Ridsdale A, Zhang L, Woulfe J, Yin X, Trapp BD, McRory JE, Rehak R, Zamponi GW, Wang W, Stys PK: NMDA receptors mediate calcium accumulation in myelin during chemical ischaemia. Nature 2006;439:988-992.

21 Yang XL, Tauchi M, Kaneko A: Quantitative analysis of photoreceptor inputs to external horizontal cells in the goldfish retina. Jpn J Physiol 1982;32:399-420.

22 Gottesman J, Miller RF: Pharmacological properties of N-methyl-D-aspartate receptors on ganglion cells of an amphibian retina. J Neurophysiol 1992;68:596-604.

23 Hartveit E, Veruki ML: AII amacrine cells express functional NMDA receptors. Neuroreport 1997;8:1219-1223.

24 Dingledine R, Borges K, Bowie D, Traynelis SF: The glutamate receptor ion channels. Pharmacol Rev 1999;51:7-61.

25 Yang XL, Wu SM: Effects of CNQX, APB, PDA, and kynurenate on horizontal cells of the tiger salamander retina. Vis Neurosci 1989;3:207-212.

26 Yang XL, Wu SM: Coexistence and function of glutamate receptor subtypes in the horizontal cells of the tiger salamander retina. Vis Neurosci 1991;7:377-382.

27 Shingai R, Christensen BN: Excitable properties and voltage-sensitive ion conductances of horizontal cells isolated from catfish (Ictalurus punctatus) retina. J Neurophysiol 1986;56:32-49. 